\title{
A farkasalma (Aristolochia clematitis L.) antimikrobás hatásának vizsgálata
}

\section{Bartha Sámuel Gergely , Papp Nóra ${ }^{1}$, Kopcsányi Márton², Mágó Martin²,} Kerényi Mónika²

${ }^{1}$ Pécsi Tudományegyetem, Farmakognóziai Intézet, 7624 Pécs, Rókus u. 2.

2 Pécsi Tudományegyetem, Orvosi Mikrobiológiai és Immunitástani Intézet, 7624 Pécs, Szigeti út 12.

Erdélyben napjainkban is élnek tradicionális gyógymódok, amelyek generációról generációra öröklődnek. Kutatómunkánk során Székelyföldön és a Szilágyságban végeztünk etnobotanikai gyújtést (2010-2016), majd a feljegyzett gyógynövények helyi alkalmazását összevetettük tudományos adatbázisok adataival. Így jelöltük ki további vizsgálatra a farkasalmát (Aristolochia clematitis, Aristolochiaceae); levelét - korábbi adatokhoz hasonlóan - az adatközlők 78\%-a említette a helyi állatgyógyászatban külsőleg sebek kezelésére. Jelen munkánk célja a növény antimikrobás hatásának tesztelése volt.

A növény levelének, szárának és gyökerének metanolos, hexános, kloroformos, etil-acetátos, butanolos és vizes kivonatát vizsgáltuk kémcsőhígításos módszerrel az alábbi törzsek esetében: Staphylococcus aureus (ATCC ${ }^{\circledR}$ 25923),

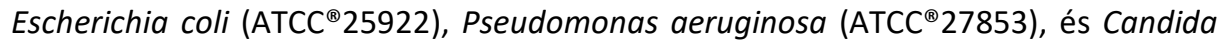
albicans (ATCC ${ }^{\circledR} 90028$ ).

A növény minden vizsgált részének vizes kivonata gátolta a $S$. aureus, $P$. aeruginosa és $C$. albicans, a szár és a levél metanolos kivonata a $P$. aeruginosa szaporodását. Vizes kivonatok esetén a növény gyökerének kivonata nagyobb gátlást fejtett ki a levél és szár kivonatokkal szemben.

Előzetes irodalmi adatok alapján a kloroformos fázissal kivonásra kerül a fajban előforduló arisztolochiasav, így valószínűsíthető, hogy az antimikrobás hatásúnak bizonyult vizes fázis a komponenst kis mértékben tartalmazza (erre vonatkozó mérést még nem végeztünk). A vizes oldatok farmakokinetikai szempontból előnyösebbek, ami ígéretes lehet az alkalmazás szempontjából. További vizsgálatokat tervezünk a növény komponenseinek meghatározására, az arisztolochiasav mennyiségi mérésére az egyes fázisokban, illetve a kivonatok klinikai törzsekre gyakorolt hatására.

Témavezetők: $\quad$ Papp Nóra (PTE, Farmakognóziai Intézet)

Kerényi Mónika (PTE, Orvosi Mikrobiológiai és Immunitástani Intézet) 